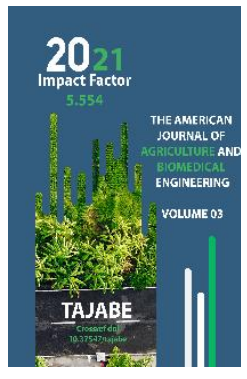

Copyright: Original content from this work may be used under the terms of the creative commons attributes 4.0 licence.

\section{The Possibility Of Increasing The Natural Resistance Of The Body Of The Karakulian Lambs By Biophysical Methods}

\author{
Rajamurodov Zaynitdin Turabovich \\ Doctor Of Biological Sciences, Professor, Samarkand State University, Uzbekistan \\ Jalilov Mukhiddin Khalimovich \\ PhD, Samarkand State Medical Institute, Samarkand, 140100, Uzbekistan \\ Akhrorov Ma'ruf Nasimjonovich \\ Assistant, Samarkand State Medical Institute, Samarkand, 140100, Uzbekistan
}

\title{
ABSTRACT
}

This article provides information on the effect of the immune status of sheep on the humoral and cellular defence systems of sheep raised in extreme conditions, irradiated with low-intensity laser light before arrival. According to the data obtained, it was found that the effect of laser light on a mothersheep affects its activity on the cellular protective components of the lambs' body.

\section{KEYWORDS}

Environmental factors, extreme conditions, immune status, Karakul breed, laser radiation, meat, biophysics, natural durability, past intensive, pasture, $\mathrm{T}$ - and $\mathrm{V}$-lymphocytes.

\section{INTRODUCTION}

The main goal of livestock farms is to increase the viability of small ruminants grazed in environmentally unfavourable conditions, increase the quantity and improve the quality of meat products and provide the market with ecologically clean products. It is known that on average $50 / 50 \%$ of ewes and males are obtained from ewes bred in mountain and foothill pastures. However, in recent years, due to the abandonment of breeding, the number of male lambs that can be slaughtered to obtain skins, especially karakul skins, has decreased, while the number of lambs that cannot be sold even when slaughtered has increased. The need to leave such lambs for breeding and get a quality meat product of 
sufficient weight from them at 12-15 months of age remains one of the current priorities.

Therefore, in addition to caring for healthy, high-viability individuals, lambs left for rearing remain a pressing challenge to increase their productivity and obtain an environmentally friendly, high-quality product $[9,4]$.

In such cases, serious attention is paid to the study of the effects of various biophysical factors that ensure the recovery of functional reserves of important adaptive systems of the organism. One of the promising methods to increase the productivity of animals, increase the natural resistance of the organism, can be considered the method of low-intensity infrared laser radiation [10]. One of the new directions of research in pastoral animal husbandry, ie karakul breeding, is the development of new work on improving the digestive processes of young lambs on the basis of biophysical methods in karakul breeding, increasing the natural resilience of the organism to increase productivity. This direction can be applied in the technological processes of animal feeding and care.

The fact that research in this area has not been conducted in the context of Uzbekistan and its prospects and opportunities has highlighted the urgency of our work. The natural resilience of the animal organism is usually understood as the ability of the organism to withstand the adverse effects of the external environment [7]. Because living organisms are an open system, they are constantly exchanging matter and energy with the environment around them. However, despite the high level of the natural resilience of animals and the need for in-depth study, the characteristics of the manifestations of reactions in the ontogenesis of karakul sheep to the effects of their biophysical methods, providing the body's natural protective functions, have not been studied in Uzbekistan.

\section{MATERIALS AND METHODS}

To study the above problems, 108 3.5-year-old ewes were selected before the fertilization season to conduct scientific and production experiments on the farm to study the immunological properties of naturally inseminated karakul lambs of the farm "Gulamdon ona chorvalari" Samarkand region, Koshrabot district.

And they were inseminated with karakul rams.

Table 1. The laser treatment of lambs in the formed groups is shown in the table below.

\begin{tabular}{|c|c|c|c|}
\hline \multirow[t]{3}{*}{ Indicators } & \multicolumn{3}{|c|}{ Groups } \\
\hline & \multirow{2}{*}{$\begin{array}{c}\text { The laser light was not } \\
\text { affected } \\
\text { Control (1) }\end{array}$} & \multicolumn{2}{|c|}{$\begin{array}{l}\text { exposed to laser light } 2 \text { times the activity } \\
\text { of the curved gland }\end{array}$} \\
\hline & & Experience (2) & Experience (3) \\
\hline Affected area & Not affected & \multicolumn{2}{|c|}{ curved gland located area } \\
\hline $\begin{array}{l}\text { Time of exposure, } \\
\text { minutes }\end{array}$ & - & \multicolumn{2}{|c|}{$1,5 \mathrm{~min}$} \\
\hline Number of effects shown & - & \multicolumn{2}{|c|}{2 times } \\
\hline Age of animals, day & - & \multicolumn{2}{|c|}{$15-20$} \\
\hline
\end{tabular}


The American Journal of Agriculture and Boimedical Engineering

IMPACT FACTOR

(ISSN - 2689-1018)

2021: 5.554

Published: March 26, 2021| Pages: $12-16$

Doi: https://doi.org/10.37547/tajabe/Volume03Issue03-03

OCLC - 1121105746

In the second half of the gestation period, the ewes were divided into two groups, control (55 heads) and experimental (53 heads). The control group sheep were not irradiated with low-intensity laser light, while the experimental group sheep were irradiated with low-intensity laser light in the second half of the gestation between the last lumbar spine and the dorsum. During the lambing period, 3 groups of male lambs born in the control and experimental groups were formed; while the control group, which was not exposed to the laser beam, formed control and 1 experimental group from lambs obtained from mother sheep, the experimental group formed 3 experimental groups from mother sheep [1, 2, $3,6]$. Experiments in healthy lambs began after the lambs selected for the experiments were examined and diagnosed with the participation of veterinarians.

\section{RESULTS AND DISCUSSION}

Given that the morphological composition of the blood, as well as the endurance of the organism, is one of the most important factors in the vital activity of the organism, we studied the indicators characterizing the protective capabilities of the organism of young karakul lambs in experiments [7, 8]. Evaluation of the protective capabilities of the experimental animals was carried out by taking into account the activity of cellular factors ( $T$ - and, $V$ lymphocytes), such as humoral (bacterial and lysozyme activity of serum BABS; LABS) of the immune system $[1,8]$. The data obtained are presented in Table 2.

Table 2. Age-related changes in immune reactivity of experimental lambs,\%

\begin{tabular}{|c|c|c|c|c|}
\hline \multirow[t]{2}{*}{ Indicators } & \multirow{2}{*}{$\begin{array}{l}\text { Age of lambs, } \\
\text { month }\end{array}$} & \multicolumn{3}{|c|}{ Гурухлар } \\
\hline & & Control (1) & Experience (2) & Experience (3) \\
\hline \multirow[t]{4}{*}{ BABS } & New born & $31,50 \pm 0,7$ & $31,78 \pm 1,1$ & $31,33 \pm 1,8$ \\
\hline & 1 month old & $34,28 \pm 1,0$ & $38,17 \pm 1,3^{*}$ & $41,13 \pm 1,6 * *$ \\
\hline & 2 months old & $42,42 \pm 1,1$ & $47,41 \pm 1,3^{*}$ & $50,08 \pm 2,1 * *$ \\
\hline & 4 months & $40,91 \pm 2,3$ & $45,47 \pm 1,5$ & $49,28 \pm 2,5^{*}$ \\
\hline \multirow[t]{4}{*}{ LABS } & New born & $25,08 \pm 1,8$ & $27,18 \pm 1,1$ & $27,09 \pm 0,9$ \\
\hline & 1 month old & $30,21 \pm 0,8$ & $32,64 \pm 1,5$ & $34,06 \pm 1,9 *$ \\
\hline & 2 months old & $35,06 \pm 0,9$ & $39,53 \pm 1,6 * *$ & $40,12 \pm 1,2 * *$ \\
\hline & 4 months & $29,72 \pm 2,9$ & $36,64 \pm 0,42 *$ & $38,34 \pm 1,6 *$ \\
\hline \multirow[t]{4}{*}{ T- lymphocytes } & New born & $22,4 \pm 0,5$ & $23,1 \pm 1,0$ & $23,0 \pm 1,3$ \\
\hline & 1 month old & $24,4 \pm 0,7$ & $26,0 \pm 0,9$ & $26,8 \pm 0,6^{*}$ \\
\hline & 2 months old & $27,6 \pm 0,8$ & $27,6 \pm 0,8^{*}$ & $29,2 \pm 0,9 *$ \\
\hline & 4 months & $26,2 \pm 0,6$ & $30,2 \pm 0,6 *$ & $31,2 \pm 0,7 * *$ \\
\hline \multirow{4}{*}{ B- lymphocytes } & New born & $17,4 \pm 1,1$ & $17,6 \pm 0,7$ & $19,2 \pm 0,6$ \\
\hline & 1 month old & $19,6 \pm 1,0$ & $21,2 \pm 1,0$ & $22,8 \pm 0,9 *$ \\
\hline & 2 months old & $22,8 \pm 0,6$ & $24,6 \pm 0,5^{*}$ & $26,8 \pm 0,8^{*}$ \\
\hline & 4 months & $23,8 \pm 1,0$ & $25,9 \pm 0,8$ & $28,0 \pm 0,9 *$ \\
\hline
\end{tabular}

Note: ${ }^{*}-\mathrm{P}<0,05 ;{ }^{*}{ }_{-} \mathrm{P}<0,001$ 
Data on the immunobiological properties of the organism of lambs of experimental groups are given in the table above. According to the data obtained, the lowest rate of humoral immunity corresponded to the initial period of the postnatal period: in experimental newly born lambs, the indicators of bactericidal and lysozyme activity of serum ranged from $31.50 \pm$ 0.7 and $25.08 \pm 1.8 \%$. There was an increase in the blood-protective capabilities (BABS and LABS) of two-month-old lambs, with experimental group lambs increasing by $1.5 \%$ and $1.4 \%$ in serum and control group lambs by $1.2-1.3 \%$, respectively. Despite the generality of age-related changes in natural endurance indicators, it should be noted that the lambs of the experimental group were distinguished by the fact that these indicators had a high concentration in the serum. During the observations, BABS and $\mathrm{LABS}$ rates were higher in the experimental group of lambs: $29.3 \%$ and $13.5 \%$ at one month of age, $17.5 \%$ and $14.8 \%$ at two months of age, $17.5 \%$ and $29 \%$ at four months of age, $3 \%$ higher than their peers in the control group $(R \leq 0.05 ; R \leq 0.001)$.

To confirm the established pattern, we considered it necessary to study the agerelated changes in the concentration of $\mathrm{T}$ - and B-lymphocytes that form the cellular types of the immune response, and observations were continued until separation from the mother. No significant differences in the concentration of T-lymphocytes in the peripheral blood of lambs were observed in the first months of life according to the studied character. However, a $10.4 \%$ predominance was found in the lambs of the experimental group on the level of Blymphocytes, which play an important role in the provision of humoral immunity. By the fourth month, an increase in the concentration of $\mathrm{T}$ - and V-lymphocytes in the blood of experimental group animals was observed compared to control group lambs.
In our opinion, this may be the effect of laser radiation on their body. At this time, it was found that the level of T- and V-lymphocytes in the peripheral blood of experimental animals was $11.3-17.0 \%$ higher than that of control group lambs $(R \leq 0.001)$. We believe that the immunocompetent cells of the lamb's understudy not only have ontogenetic properties but in our view depend to some extent on the influence of biophysical factors. With the above-mentioned regularity, the rate of increase of $\mathrm{T}$ - and $\mathrm{V}$-cells in the peripheral blood of the lambs of the experimental group was determined.

Several characteristics specific to all studied animals were identified, such as increased growth and development of lambs, increased activity of BABS, LABS, and the low manifestation of natural resistance of the organism in the first months.

Also, the predominance of the protective capacity of the lambs of the experimental group on the level of humoral, cellular factors of natural protection was determined.

It should be noted that the amplitude of the detected changes did not exceed the physiological norm.

\section{CONCLUSION}

Summarizing the results of our studies, we can conclude that the influence of biophysical factors on the body of lambs in the first months of ontogeny activates the mechanisms of natural resistance, which in turn ensures rapid growth and development of lambs.

\section{REFERENCES}

1. Afans'ev M. A. Razrabotka priema povyshenija produktivnosti, rezistentnosti molodnjaka ovec na 
osnove biofizicheskih metodov. Avtoref. dis. ... kand. s.-h. nauk: Stavropol', 2020,-24 S.

2. Moskvin, S. V., \& Achilov, A. A. (2008). Osnovy lazernoj terapii. OOO" Izdatel'stvo" Triada".896 c.

3. Vasil'ev, V. S., Lisichenko, N. L., \& Vasil'eva, O. V. (2012). Dejstvie lazernogo sveta raznoj poljarizacii na fermentativnye sistemy kletok. Plodovodstvo i jagodovodstvo Rossii, 33, 78-85.

4. Omarov, A. A. (2016). Mjasnaja produktivnost' molodnjaka ovec pri raznom urovne kormlenija. Ovcy, kozy, sherstjanoe delo, (2), 39.

5. Okazov, T., \& Teziev, T. (2008). Primenenie lazeropunktury dlja teljat. Molochnoe i mjasnoe skotovodstvo, (4), 34-35.

6. Okazov, T. A. (2009). Rost, razvitie, rezistentnost' teljat i molochnaja produktivnost' korov pri lazeropunkture (Doctoral dissertation, Okazov Temurbolat Aslanovich). $24 \mathrm{~s}$.

7. Osin, A. Ja., Ickovich, A. I., \& Gel'cer, B. I. (1999). Lazernaja terapija $\mathrm{V}$ pul'monologii. Dal'nauka. $222 \mathrm{~s}$.

8. Strelycheva, K. A., Bruk, T. M., \& Osipova, N. V. (2018). Ocenka nekotoryh biohimicheskih pokazatelej krovi u vysokokvalificirovannyh shorttrekovikov pri sochetannom dejstvii specificheskoj fizicheskoj nagruzki i nizkointensivnogo lazernogo izluchenija. Vestnik Rossijskoj voennomedicinskoj akademii, (1), 108-110.

9. Selionova, M. I., \& Bobryshova, G. T. (2016). Ovcevodstvo Stavropol'skogo kraja, nastojashhee i budushhee. Ovcy, kozy, sherstjanoe delo, (1), 4-7.

10. Samodelkin, A. G., Ivashhenko, M. N., \& Kuimov, I. A. (2014). Vlijanie neinvazivnogo sposoba lazernogo obluchenija krovi na gematologicheskie pokazateli u molodnjaka lisic $\mathrm{v}$ period adaptacii organizma posle ot\#ema. Sovremennye problemy nauki i obrazovanija, (6), 1442-1442. 